\title{
Moldovos saugumo strategija: nuolatinio neutraliteto problema
}

$1991 \mathrm{~m}$. nepriklausomybę paskelbusi Moldova netruko susidurti su rimtomis grèsmėmis nacionaliniam saugumui, iš kurių viena stipriausių- konfliktas su separatistiniu Padniestrès regionu ir Rusijos kariniu pajègu dislokavimas šalies teritorijoje. Tuomet Moldova pasirinko nuolatinio neutraliteto saugumo strategiją, nepaisydama to, kad šalis neatitiko net minimaliu neutraliteto sąlygu. Skubotai pasirinkta neutraliteto strategija ne tik neprisideda prie grèsmiu Moldovos saugumui sumažinimo, bet ir kelia kliūčiu šaliai pereiti prie labiau jos poreikius atitinkančios saugumo strategijos. Dar daugiau, deklaruotas nuolatinis neutralitetas gali tapti kliūtimi Moldovai siekti strateginio tikslo - integracijos į ES. Straipsnyje aptariami Moldovos neutraliteto ypatumai ir pagrindinès šios saugumo strategijos problemos. Taip pat analizuojami Moldovos neutraliteto veiksniai, žvelgiant iš skirtingu teoriniu perspektyvu, bei apžvelgiamos Moldovos saugumo dilemos po Rusijos-Gruzijos karo.

\section{Ivadas}

Moldova - maža Rytų Europos valstybè ${ }^{1}$, esanti tarp Ukrainos ir Rumunijos - tarptautinės arenos veikëjų dèmesi patraukė 2009-uju balandžio mènesio pradžioje, kai po masiniu falsifikaciju lydimų parlamento rinkimu šalies gyventojai sukilo prieš suklastotą valdančiosios komunistų partijos pergalę, reikalaudami surengti naujus rinkimus. Nors šie Moldovos įvykiai "spalvos" neigavo, juos galima vadinti naujo etapo Moldovos politiniame gyvenime pradžia². Balandžio mėnesio protestai ir po jų vykę procesai į pirmą planą iškèlè šalies demokratizacijos problemas, tačiau buvo prisiminti ir ilgą laiką ignoruoti užsienio ir saugumo politikos paradoksai.

Moldovos saugumo problematikos aktualumas nekelia abejoniu jau vien

\footnotetext{
* Mgr. Laura Kirvelyte - Generolo Jono Žemaičio Lietuvos karo akademijos vadų ir jaunesniujų štabo karininkų kursų dėstytoja. Adresas: Šilo g. 5A, 10322 Vilnius, tel. (8-5) 2103569, el. paštas laura.kirvelyte@ gmail.com

${ }^{1}$ Moldovos priskyrimas vienam ar kitam regionui - diskusijų objektas. Skirtinguose šaltiniuose šalis yra priskiriama skirtingiems regionams: Rytų Europai, Pietryčių Europai, Juodosios jūros regionui ar netgi Balkanams.

${ }^{2}$ İvykiai Moldovoje ,revoliucija“ nevadinami dẻl keleto priežasčių. Pirma, valdžios pasikeitimas vyko grynai instituciniu keliu: pirmalaikiai rinkimai buvo surengti ne protestuotojams reikalaujant, o opozicinėms partijoms du kartus iš eilės neparemus komunistų kandidato i prezidento postą. Antra, demokratišku jẻgų atejjimas i valdžią kol kas yra laikinas - komunistams pasinaudojus tuo pačiu prezidento rinkimų mechanizmu, 2010 m. antroje pusèje šalyje gali įvykti antri iš eilès pirmalaikiai parlamento rinkimai.
} 
dèl to, kad Moldova yra mažoji valstybė, esanti dviejų konfrontuojančių galių interesu susikirtimo erdvëje (tokia situacija vadinama „mažosios valstybès paradoksu“). Visgi Moldovos saugumo klausimas nacionalinejje ir tarptautinëje darbotvarkëje iki šiol būdavo nepelnytai pamirštamas, nepaisant to, kad savotiška išimtimi tarp posovietinių šalių galima laikyti tiek šalies saugumo situaciją, tiek jos sprendimą.

Visu pirma, Moldova jau beveik du dešimtmečius nesėkmingai siekia ,ị̌saldyto" konflikto su atsiskirti siekiančia Padniestre sureguliavimo. Konfliktas su Padniestre yra ne tik pagrindinis grèsmių Moldovos saugumui „,šaltinis“", bet ir kliūtis darniai šalies plètrai.

Antra, 2009 m. suejjo lygiai dešimt metų nuo 1999 m. Stambule vykusio Europos saugumo ir bendradarbiavimo organizacijos (ESBO) viršūnių susitikimo, kurio metu Rusija prisiemè įsipareigojimą per keletą metų iš Gruzijos ir Moldovos teritoriju išvesti savo karines pajègas. Moldovos atžvilgiu Rusija Stambulo įsipareigojimų neįvykdè ir šiuo metu net nebeužsimena apie kariniu pajègų išvedimo proceso atnaujinimą. Taigi Moldovos saugumo situaciją ypač apsunkina neterminuotas ir aiškios perspektyvos neturintis užsienio valstybès karinių pajègų buvimas jos teritorijoje.

Galiausiai 2008 m. rugpjūti įsiplieskęs Rusijos-Gruzijos karas nuskambëjo kaip perspèjimas Moldovai, kad šioji galinti tapti kita Rusijos agresijos auka. Juolab kad Moldova, kaip ir Gruzija, siekia ištrūkti iš Rusijos įtakos erdvės, o narystès ES siekį įvardija kaip strateginį šalies tikslą (Gruzijos atveju tai buvo narystė NATO).

Dešimtojo praẻjusio amžiaus dešimtmečio pradžioje dar visai jauna Moldovos valstybè vylèsi, kad nuolatinis neutralitetas, užfiksuotas Konstitucijoje ir strateginiuose dokumentuose, „nuramins" Rusiją ir Padniestrę bei padès sumažinti kylančias grèsmes šalies saugumui. Visgi su neutralitetu sietos viltys, galima sakyti, nepasiteisino - šiandien Moldova susiduria su tomis pačiomis grèsmėmis nacionaliniam saugumui, o neutraliteto strategija netgi grasina tapti kliūtimi šaliai siekti strateginių tikslų.

Kaip rodo tarptautine praktika, neutraliteto strategiją mažosios valstybės renkasi siekdamos išbalansuoti tarp dviejų konfrontuojančių galių. Labai dažnai mažosios valstybès neutralumas tiesiogiai susijęs su šios ekonominiais interesais - valstybè siekia gauti ekonominès naudos iš bendradarbiavimo su abejomis galiomis, todèl yra suinteresuota "eliminuoti“ saugumo politikos klausimus iš bendradarbiavimo darbotvarkès. Vis dèlto pažymètina, kad Moldovos neutraliteto strategija nuo pat pradžių buvo ne balansavimo, o „neveikimo“" strategija.

Moldovos akademiniame diskurse kritikos šalies saugumo strategijai protrūkis pastebimas nuo 2005-uju, kuomet buvo iškeltas šalies eurointegracijos tikslas. Gausus įdirbis šioje srityje priklauso Moldovos „smegenų centrams“ (angl. think tanks): IDIS Viitorul, Užsienio politikos asociacijai (Asociația pentru Politică Externă), Moldovos pro-Marshallo centrui (Centrul Pro Marshall din Republica Moldova), Moldovos NATO informacijos ir dokumentacijos centrui (Centrul informare şi documentare privind NATO din Moldova). Visgi bandymai realiai svarstyti kitas saugumo pasirinktis kol kas vangūs. 
Pirma, Moldovos akademinëje bendruomenëje pastaruoju metu pastebimas polinkis remti kitą kraštutinumą - aljansą su NATO (galima paminèti IDIS Viitorul ekspertų parengtą studiją „Ar pasitikime NATO? Paaiškinimas, kodèl Moldovai reikètu prisijungti prie NATO“ (,In NATO We Trust? Explaining Why Moldova Would Need to Join NATO“)). Be to, Moldovos saugumo ekspertu darbuose daugiau dèmesio skiriama saugumo politikos partneriu pasirinkimo problemai, o ne platesniam saugumo strategijos klausimui. Kitaip tariant, ieškoma atsakymo į klausimą „,su kuo?" , o ne „kaip?“. Antra, akademinès minties ryšys su politika Moldovoje visą ši laikotarpi buvo menkas, tad pozityviu pokyčiu šalies saugumo strategijos srityje vargu ar buvo galima tikètis.

Šiame straipsnyje pristatomo tyrimo tikslas - atsakyti į klausimą, kodèl Moldova pasirinko neutraliteto saugumo strategiją ir kokios jos perspektyvos. Pirmojoje straipsnio dalyje aptariamos Moldovos geopolitinès situacijos sąsajos su šalies saugumo strategija. Antrojoje dalyje, remiantis Moldovos strateginiu dokumentų analize, apžvelgiama Moldovos saugumo strategijos raida bei aptariamos "moldaviškojo" neutraliteto ypatybės. Trečioji straipsnio dalis skirta klausimui, kodèl Moldova iki šiol išlaikè paradoksalu savo „neutralumą“. Žvelgiant iš trijų skirtingų tarptautinių santykių teorinių prieigu - realizmo, pliuralizmo ir konstruktyvizmo - analizuojama, iš kur kyla neutralumo poreikis, kaip pasireiškia šios saugumo strategijos nepakankamumas ir kokios yra Moldovos saugumo darbotvarkès perspektyvos.

\section{Moldova geopolitinèje kryžkelèje}

Po šaltojo karo pabaigos nepriklausomybę paskelbusi Moldova kartu su kitomis pokomunistinėmis valstybėmis atsidūrẻ vadinamojoje „pilkojoje zonoje", pasižyminčioje "galios vakuumu“ didžiuju galių atžvilgiu.

Moldovai, kartu su kitomis „pilkosios zonos“ valstybèmis, didžiuju galiu (Rusijos ir JAV) geopolitiniuose koduose tenka barjero vaidmuo ${ }^{3}$. Tačiau, žvelgiant iš regioninės perspektyvos, Moldovos geopolitinė funkcija priklauso nuo Ukrainos - geopolitinio Rytų Europos centro - vaidmens. Vakarams (visu pirma - JAV) Moldova yra placdarmas įtakos Ukrainoje plètrai ir konsolidavimui (demokratiškos ir provakarietiškos Moldovos egzistavimas sudarytu palankesnes sąlygas Ukrainos demokratizacijai). Tačiau Rusijai Moldova yra barjeras, blokuojantis Vakarų įtaką Ukrainai (stabili prorusiška Moldovos geopolitinė orientacija padètų Rusijai į savo įtakos sferą "grąžinti“ Ukrainą).

$1991 \mathrm{~m}$. rugpjūčio 27 d. nepriklausomybę deklaravusi Moldova nesvarstè grįžimo į Rusijos geopolitinę erdvę galimybès - valstybės tikslas buvo grįžti prie „istorinès tiesos“ ir atkurti glaudžius santykius su Rumunija, galbūt netgi suformuoti bendrą valstybę. Toks scenarijus būtų buvęs naudingas Vakarams,

\footnotetext{
${ }^{3}$ Serebrian O., „Perspectivele geostrategice ale Republicii Moldova” in Studii internationale:Viziuni din Moldova. Publicație periodică ştințifico-metodică, Nr. 3(4), 2007, p. 34.
} 
visų pirma - JAV, nes „suskaidytų“ vadinamąją posovietinę erdvę, o tai apsunkintų Rusijos galios atkūrimą „pilkojoje zonoje“. Tačiau Rusija nesusitaikè su įtakos buvusiems sąungininkams praradimu. Po Moldovai nesėkmingai pasibaigusio Rusijos išprovokuoto konflikto su Padniestre Rusija ilgam „nukreipé “ Moldovos geopolitinès orientacijos vektorių nuo Vakarų buvusios sovietinès erdvès link.

„Priverstinę" prorusišką geopolitinę orientaciją Moldova išlaikẻ ilgiau nei dešimtmeti. Geopolitinio vektoriaus krypties pokytis atsispindejjo ir šalies vidaus politikoje - nuo $1994 \mathrm{~m}$. parlamento rinkimu prorumuniškos politinès jègos parlamente nè karto neturejo daugumos ${ }^{4}$, o $2001 \mathrm{~m}$. parlamento rinkimus laimèjo komunistų partija su ypač prorusiška programa ${ }^{5}$.

Balansavimo tarp dviejų didžiujuc galių keliu Moldova pasuko apie 2005-uosius metus, kai parlamento rinkimus vèlgi laimejjo ta pati komunistu partija, tik šį kartą savo programoje strateginiu šalies tikslu ịvardijusi narystès Europos Sajungoje siekį. Tačiau komunistų eurointegracinè politika buvo vykdoma gana kukliai ir formaliai ${ }^{6}$, o šalies geopolitinès orientacijos vektorius „blaškèsi“ tarp Rusijos ir Vakarų. Po 2009 m. liepos 29 d. pirmalaikiu parlamento rinkimų šalyje į valdžią atëjus keturioms proeuropietiškoms partijoms, susijungusioms į koaliciją „Už Europos integraciją“, Moldova ryžtingai pasuko provakarietiškos geopolitinės orientacijos link.

Globaliu lygmeniu Moldova vis dar lieka ,pilkojoje zonoje“ tarp Rusijos ir Vakaru, tačiau šiuo metu jau turi nemažai institucionalizuotų bendradarbiavimo su Vakarais instrumentų: Moldova yra įtraukta į ES Rytu partnerystès iniciatyvą, artimiausiu metu bus pradètos derybos dèl Asociacijos sutarties su ES, su NATO šalis bendradarbiauja pagal 2006 m. pasirašytą Individualios partnerystės veiksmų planą. Regioninis Moldovos kontekstas taip pat palankus provakarietiškai šalies orientacijai stiprinti: Moldova sparčiai gerina ryšius su ES ir NATO nare Rumunija, kita Moldovos kaimynè - taip pat eurointegracijos keliu eiti siekianti Ukraina. Moldovos bendradarbiavimas Juodosios jūros regione taip pat prisideda prie vakarietiškų vertybių ir proeuropinių aspiraciju sklaidos. Netgi posovietinejje erdvëje Moldova priklauso provakarietišku vadinamam Gruzijos, Ukrainos, Azerbaidžano ir Moldovos blokui GUAM.

Tačiau lokaliu lygmeniu Moldova susiduria su didžiausiais iššūkiais ir kliūtimis provakarietiškai geopolitinei orientacijai įtvirtinti ir išlaikyti. Visų pirma, „ǐ̌šldytas“ konfliktas su Padniestre yra pagrindinė Rusijos įtakos Moldovai išlaikymo priežastis. Kaip pastebi ekspertai, po konflikto su Padniestre ,į̌saldymo“ Moldova tapo valstybe su dviem vyriausybėmis, dviem vèliavo-

\footnotetext{
${ }^{4}$ Josanu Y., Juc V., Rusandu I., Sisteme politice tranzitorii din Europa de Sud-Est (studiu comparat), Chişinău, 2008, p. 77.

${ }^{5}$ Waters T., The "Moldovan Syndrome" and Re-rusification of Moldova: Forward into the Past!, G105, Conflict Studies Research Centre, February 2002, p. 3-4.

${ }^{6}$ Molodilo D., ,Republic of Moldova Within the European Security System: Partners, Challenges, Perspectives" in European and NATO Neighbouring Policies - New Dimensions Forregional Cooperation, Training seminar, Chisinau, Republic of Moldova, November 28-29, 2007, p. 87.
} 
mis ir, kas blogiausia, dviem kariuomenėmis ${ }^{7}$. Dar daugiau, jei šis konfliktas pereitų į aktyvią fazę, kaip tai nutiko 2008 m. rugpjūtį Gruzijoje, iškiltų reali grèsmė Moldovos išlikimui ar bent jau grèstų viso ligšiolinio ,įidirbio“ bendradarbiaujant su Vakarais praradimas. Antra, provakarietišką Moldovos geopolitinę orientaciją riboja ir sudètinga demografinė padètis. Šalyje - vienas didžiausių ekonominès migracijos mastų visoje posovietinëje erdvẻje. $2004 \mathrm{~m}$. atliktų tyrimų duomenimis, ekonominę emigraciją yra pasirinkę per 600 tūkst. darbingo amžiaus Moldovos piliečiu arba kas trečias darbingas moldavas ${ }^{8}$. Ekspertų teigimu, šiuo metu ekonominių emigrantų skaičius gali būti net iki dviejų kartų didesnis. Tokiu būdu „išsklaidoma“ kritinė provakarietiškai mąstančiu gyventojų masė ir sudaromos sąlygos šalies viduje susiformuoti kritinei masei, pasisakančiai už glaudžius santykius su Rusija.

\section{Moldovos saugumo strategijos raida}

Dešimto praëjusio amžiaus dešimtmečio pradžioje susiklosčiusi sudètinga saugumo situacija, kurią dar labiau komplikavo nelengva politinė ir ekonominè transformacija, paskatino Moldovą pasirinkti neutralitetą kaip kompromisinę šalies saugumo strategiją. Visgi sprendimas dèl nuolatinio neutralumo buvo priimtas gana skubotai, neįvertinus Moldovos vidinès ir išorinès situacijos. Šalis nuo pat neutraliteto įtvirtinimo akimirkos visiškai neatitiko neutralioms valstybėms keliamų reikalavimu, taip pat Moldovos neutraliteto negarantavo jokia išorinè galia ir nepripažino tarptautinè bendruomenè. Paradoksalu tai, kad šiuo metu nuolatinis Moldovos neutralumas yra tapęs savotiška šalies saugumo politikos „aksioma“, kurios pagrįstumas ir tikslingumas politiniuose debatuose nesvarstomas.

\subsection{Saugumo politikos raida strateginiuose dokumentuose}

Suverenios valstybės saugumo strategija - kompleksinis darinys, apibūdinantis valstybės „elgseną“ siekiant užtikrinti savo saugumą nuo išorès ir vidaus grèsmių. Taigi saugumo strategija apima ir strateginius dokumentus, ir kasdienini politinį šalies gyvenimą. Svarbu atkreipti dėmesi, kad nors ne visuomet šalies saugumo politikos kryptys yra fiksuojamos strateginiuose dokumentuose, valstybès saugumo politikos gairiu įtvirtinimas juose yra svarbus dèl keleto priežasčių. Visų pirma, tokiu būdu kiti tarptautinès arenos veikëjai yra „informuojami“ apie šalies užsienio ir saugumo politikos kryptis.

\footnotetext{
${ }^{7}$ King Ch., The Moldovans. Romania, Russia and the Politics of Culture. Stanford University, 2000, p. 229

${ }^{8}$ Мошняга В., “Международная трудовая миграция молдавского населения и проблема денежных переводов в человеческом и институциональном измерении" in Studii internationale: Viziuni din Moldova. Publicație periodică ştințifico-metodică, Nr. 4(5), 2007, p. 23.
} 
Antra, strateginiai dokumentai padeda išlaikyti valstybės užsienio ir saugumo politikos krypčių tęstinumą, ypač - valdžios kaitos metu.

Moldova, lyginant su kitomis pokomunistinemis valstybėmis, gana anksti suformavo išbaigtą strateginių dokumentų hierarchiją. Svarbiausiu strateginiu dokumentu laikoma Nacionalinio saugumo koncepcija buvo priimta 1995 m. (nauja dokumento versija parlamente patvirtinta 2008 m. gegužę), iki šiol veikianti Užsienio politikos koncepcija taip pat buvo priimta 1995 m., tais pačiais metais patvirtinta Karinė doktrina. Tačiau, nors ir turėdama klasikinę "formą", strateginių Moldovos dokumentu sistema susiduria su atitikties esamai geopolitinei ir saugumo situacijai problema.

Pirmajame nepriklausomos Moldovos dokumente - 1991 m. rugpjūčio 27 d. priimtoje Nepriklausomybès deklaracijoje - jokios užuominos į šalies neutralumą nėra. Dar daugiau, kalbant apie Moldovos siekį tapti universaliu ir specializuotų tarptautinių institucijų dalimi, išskiriama šalies narystės Europos saugumo ir bendradarbiavimo konferencijoje (dabartinès ESBO pirmtakè) ir prisijungimo prie jos mechanizmų svarba'.

$1994 \mathrm{~m}$. liepos 29 d. priimtos Konstitucijos tonas jau iš esmès skyrèsi nuo Nepriklausomybès deklaracijos - Konstitucijos 11 straipsnyje įtvirtintas nuolatinis neutralitetas ${ }^{10}$. Neutraliteto fiksavimas Konstitucijoje - labai tvirtas saugumo politikos pareiškimas, nuo kurio atsitraukti sudètinga tiek politiškai, tiek procedūriškai. Be to, atkreiptinas dèmesys, kad nuolatinį neutralumą deklaravo tik ką nepriklausoma tapusi valstybė, kurios užsienio ir saugumo politikos kryptys dar tik formavosi.

1995 m. gegužę priimta Nacionalinio saugumo koncepcija - pagrindinis strateginis šalies dokumentas - atkartojo Konstitucijoje įtvirtintą nuolatinio neutralumo principą ${ }^{11}$, tačiau plačiau jo nepaaiškino. Siame dokumente ypač daug dėmesio skiriama vidinėms grèsmėms Moldovos saugumui (kèsinimasis į šalies konstitucinę santvarką, socialinių neramumų kurstymas, šalies ekonominio, technologinio ir gynybinio potencialo mažinimas ir pan.), o išorinès grèsmès įvardijamos gana abstrakčiai ir atrodo mechaniškai perkeltos iš "chrestomatinių" saugumo dokumentų. Pavyzdžiui, praejjusio dešimtmečio viduryje Moldovai ne tokia aktuali terorizmo grèsmè įvardyta atskiru punktu. Kita vertus, po nesèkme pasibaigusiu ginkluotų susiremimų su Padniestre Moldovos teritorijoje likusios Rusijos 14-osios armijos keliamai grèsmei įvardyti pasirinkta ypač plati „tiesioginès agresijos prieš Moldovos teritoriją" formuluotè, o tuo metu aktualiausia separatizmo grèsmè išvis nepaminèta, pakeičiant ją „konfliktų Moldovos aplinkoje grèsme“.

\footnotetext{
${ }^{9}$ Lege privind Declarația de Independență a Republicii Moldova, Nr.691-XII din 27.08.91, Monitorul Oficial al R.Moldova $\mathrm{nr} .11-12 / 103$ din 30.12.1991.

${ }^{10}$ Constituția Republicii Moldova, http://www.presedinte.md/const.php?page=8100\&lang=rom\#8100 [2009-11-15]

${ }^{11}$ Hotarirea Parlamentului Republicii Moldova cu privire la aprobarea Concepției securității naționale a Republicii Moldova şi la formarea Consiliului coordonator pentru elaborarea proiectelor de legi şi altor acte normative care vor reglementa construcția, pregătirea și folosirea Forțelor Armate, Nr.445-XIII din 05.05.95, Monitorul Oficial al R.Moldova nr.35/399 din 29.06.1995.
} 
Nacionalinio saugumo koncepcijos tobulinimo ketinta imtis $1998 \mathrm{~m}$., tačiau dèl Rusijos krizės, turëjusios sunkiu pasekmių nuo Rusijos rinkos priklausomai Moldovos ekonomikai, šio tikslo teko laikinai atsisakyti ${ }^{12}$.

$2005 \mathrm{~m}$. pabaigoje tuometinis šalies prezidentas Vladimiras Voroninas dekretais pavedė suformuoti dvi komisijas Nacionalinio saugumo koncepcijai ir Užsienio politikos koncepcijai tobulinti ${ }^{13} .2008 \mathrm{~m}$. gegužę parlamentas pritarẻ naujajai Nacionalinio saugumo koncepcijai. Lyginant su pirmtake, šioji jau yra gerokai konkretesnè, labiau pabrèžiamos ne vidinès, o išorinès grèsmės, pirmą vietą grèsmių sąraše užima konfliktas su Padniestre ir grèsmė šalies teritoriniam integralumui. Visgi esminiu Moldovos pirmosios Nacionalinès saugumo koncepcijos spragų naujasis dokumentas neužpildè.

Visų pirma, naujasis dokumentas susilaukè kritikos jau vien dèl formos. Moldovos Nacionalinio saugumo koncepcijoje numatyta, kad šio dokumento pagrindu bus parengta Nacionalinio saugumo strategija, numatanti šalies saugumo užtikrinimo būdus, mechanizmus, saugumo ir gynybos sektoriaus finansavimą bei šio sektoriaus reformavimą ${ }^{14}$. Kyla klausimas, kodèl 2008 m. gegužę priimtas dokumentas neapima aukščiau įvardytų aspektų. Kaip rodo tarptautinė praktika, pagrindines saugumo politikos gaires nubrěžiantị dokumentą galima formuluoti tiek kaip koncepciją, tiek kaip strategiją. Jei koncepcijos forma buvo laikoma netinkama išdesstyti tikslams ir priemonèms, užtikrinantiems nacionalinį saugumą, tuomet lieka neatsakyta, kodèl Moldovos valdžia, užuot priiminëjusi antrą iš eilès Nacionalinio saugumo koncepciją, iš karto nerengè Nacionalinio saugumo strategijos.

Pastebima tendencija, kad pagrindines šalies saugumo politikos kryptis reglamentuojantį dokumentą vadinti ",koncepcija“ labiau linkusios yra posovietinès valstybės, taip siekdamos neva "sušvelninti“ dokumento pobūdị ${ }^{15}$. Moldovos atveju, dar svarstant Nacionalinio saugumo koncepcijos projektą, buvo siūlymu pavadinti dokumentą strategija, tačiau, greičiausiai bijantis neigiamos Rusijos reakcijos, to padaryti nesiryžta.

Antra, Nacionalinio saugumo koncepcija perėmè savo „pirmtakès" turinio trūkumus. Dokumente atkartojamas, bet neišplètojamas ir išsamiai nepaaiškinamas nuolatinio neutraliteto principas, papildant ji tik nuostata, kad Moldova negali tapti karinių aljansų dalimi. Kalbant apie Moldovos padèti tarptautinejje arenoje, Nacionalinio saugumo koncepcijoje vienu metu numatoma ir eurointegracijos politika, ir ryšių su Nepriklausomų valstybių sandrauga (NVS) stiprinimas. Akivaizdu, kad šie du tikslai yra nesuderinami ir vienas

\footnotetext{
${ }^{12}$ Mînzărari D., Proiectul Concepției securității naționale - test decisiv pentru elita politică moldovenească, Discussion paper No. 1 August 2007, IDIS Viitorul, p. 14.

${ }^{13}$ Leşanu A., „Concepția Securității naționale: un document strategic pentru scopuri tactice“ in Political and Security Statewatch, Buletin analitic lunar de IDIS Viitorul, Mai 2008 Nr. 5 (12), p. 9.

${ }^{14}$ Lege Nr. 112 din 22.05.2008 pentru aprobarea Concepției securității naționale a Republicii Moldova Publicat : 03.06.2008 în Monitorul Oficial Nr. 97-98 art Nr : 357.

${ }^{15}$ Mînzărari D., Proiectul Concepției securității naționale - test decisiv pentru elita politică moldovenească (note 12), p. 6.
} 
kitą neutralizuoja ${ }^{16}$. Dar daugiau, dokumente kalbant apie bendradarbiavimą su NATO, pakartotinai pabrèžiama, kad Moldova nesiekia tapti Aljanso nare. Iš esmès to teigti nebūtina, nes Moldovos santykis su kariniais blokais (ne tik NATO) yra išdėstytas apibrèžiant neutraliteto principą. Kita vertus, NATO išskyrimas gali neigiamai paveikti Moldovos ir NATO bendradarbiavimo plètrą ateityje.

Trečia, prièmus naują Nacionalinio saugumo koncepciją, Užsienio politikos koncepcija taip ir liko nepakeista (nors naujosios Užsienio politikos koncepcijos projektas parengtas buvo). Taigi šiuo metu Moldovos užsienio politikos kryptis numato dar $1995 \mathrm{~m}$. patvirtintas dokumentas, kuris šiuo metu yra visiškai atgyvenęs ir nebeatitinka pakitusios tarptautinės ir regioninės situacijos. 1995 m., kai buvo tvirtinama Užsienio politikos koncepcija, integracija i ES į Moldovos prioritetų sąrašą neįejo, o dokumente numatytas tam laikmečiui realesnis prioritetas - integracija ic NVS ${ }^{17}$. Šiuo metu Nacionalinio saugumo koncepcija numato integraciją i ES, Užsienio politikos koncepcija - integraciją i NVS. Iškyla strateginių dokumentų nesuderinamumo problema, kuri abu dokumentus padaro tik formalius, palikdama Moldovos saugumo politiką be realaus pagrindo.

Mažosios valstybės, veikdamos tarptautinëje arenoje, dažnai yra linkusios minimizuoti riziką, o ne maksimizuoti galimą laimèjimą ${ }^{18}$. Tai lemia atsargią, reaktyvią užsienio ir saugumo politiką. Tačiau Moldovos atveju šalies geopolitinės aplinkos ir orientacijos pokyčius atspindi tik užsienio praktinė politika, o saugumo politika yra tarsi atsieta nuo šių procesų. Todèl Moldovos saugumo strategija, suformuota 1994-1995 m., taip ir liko ,į̌̌aldyta“.

Moldovos saugumo politikos paradoksalumo priežastys susiję su tuo, kad strateginiai Moldovos dokumentai buvo priimami visų pirma siekiant „,informuoti“ išorinius veikëjus (pirmiausia - Rusiją) apie šalies veikimo saugumo srityje kryptis, tačiau ilgainiui šie dokumentai tapo "amžinuoju stabdžiu“, trukdančiu šaliai pasirinkti tinkamesnį nacionalinio saugumo užtikrinimo būdą. Taigi šalies saugumo strategija atsidūrè savotiškuose "spąstuose“.

\subsection{Nuolatinio neutraliteto problemos}

Vienas aktualiausių ir daugiausia diskusijų keliančių Moldovos saugumo politikos klausimu - deklaruotas nuolatinis neutralitetas.

Moldovos neutraliteto strategija nuo pat pradžių buvo ne savarankiškas

\footnotetext{
${ }^{16}$ Grosu V., „Considerații privind Contepția securității naționale a Republicii Moldova“, Securitatea naționala - imperativ strategic, Jurnal academic Mai 2008, ediția 9, Centrul informare şi documentare privind NATO din Moldova, p. 12.

${ }^{17}$ Munteanu I. et al, 100 cele mai presante probleme ale Republicii Moldova in 2006, Studiu de analiză, IDIS Viitorul, Chişinău, 2006, p. 187.

${ }^{18}$ Handel M. I., Weak States in the International S ystem. London: Frank Cass, 1970, p. 52-53.
} 
racionalus pasirinkimas, o šalies „,neutralizavimo“ pasekmé ${ }^{19} .1991$ m. rugpjūčio $27 \mathrm{~d}$. Moldova deklaravo nepriklausomybę, po ko buvo laukiama, optimistinio scenarijaus atveju, - susijungimo su Rumunija, realistinio scenarijaus atveju - glaudžių ryšių su kaimyne. Rusija tuomet pabūgo, kad gali prarasti buvusią sajungininkę, ir dejjo visas pastangas, kad Moldova pasuktu bent jau neutraliteto keliu. Stipriausias Rusijos koziris buvo $1990 \mathrm{~m}$. rudenį įsiplieskęs iki šiol nesureguliuotas konfliktas su Padniestre. Rusijai ịsikišus ị ši konfliktą, Padniestreje, kuri de jure yra Moldovos dalis, buvo dislokuotos Rusijos karinès pajėgos. Taigi 1994-aisiais priimant Konstituciją - pirmajjį dokumentą, oficialiai įtvirtinantį neutraliteto statusą - Moldova turëjo atsiskyrimo siekiantį regioną ir jame dislokuotas užsienio valstybės karines pajègas. Neutraliteto atmetimas tuo metu galejo lemti ir Rusijos kariniu pajëgu panaudojimą prieš Moldovą, ir galutinį Padniestrès atsiskyrimą. Reaguodama į susiklosčiusią situaciją, Moldova prisièmé „deklaratyvu“" neutraliteto statusą.

Dešimto praëjusio amžiaus dešimtmečio pradžioje Moldovos valdžia visgi turëjo dar keletą priežasčiu, dèl kurių ji buvo linkusi deklaruoti (ne pasirinkti, nes neutralitetas niekada realiai taip ir neveikè) neutraliteto strategiją. Visu pirma, deklaruotas neutralitetas Moldovai tapo argumentu, leidusiu, nepaisant egzistavusio spaudimo, likti nuošalyje nuo saugumo ir karinių struktūru, kuriose Rusija dominuoja (tokių kaip Kolektyvinio saugumo sutarties organizacija) ${ }^{20}$. Moldova NVS nare tapo $1991 \mathrm{~m}$. pabaigoje vedama tikslo išlaikyti abipusiškai naudingus ekonominius ir socialinius ryšius, tačiau bendrumo užsienio ir saugumo politikos srityse Moldova vengè. 1993 m. Moldova, kaip ir Gruzija bei Azerbaidžanas, NVS ịstatus pasirašè su išimtimi, kad nedalyvaus karinëjepolitinëje dimensijoje ${ }^{21}$. Visgi spaudimas iš Rusijos pusės Moldovai prisijungti prie Kolektyvinio saugumo sutarties organizacijos jaučiamas iki šiol ${ }^{22}$.

Antra, Moldovos Konstitucija buvo patvirtinta jau po nesėkmingai Moldovai pasibaigusio Moldovos ir Padniestrès ginkluotuju pajėgų susidūrimo 1992 metų vasarą. Neutralumo įtvirtinimas buvo viena iš sąlygu, leidusių išlaikyti kompromisą tiek su atsiskirti siekiančiu regionu, tiek su Rusija, Padniestrëje dislokavusia savo karines pajejgas. Dar daugiau, Moldovos valdžia vylėsi, kad neutralitetas paskatins Rusiją greičiau išvesti savo karines pajėgas iš šalies teritorijos - jei Rusija nori išlaikyti Moldovą neutralią, ji privalanti gerbti neutralumo principa, reikalaujantị užsienio valstybių karinių pajègu nebuvimo neutralios valstybès teritorijoje.

Trečia, kai kurie ekspertai teigia, kad neutralitetas leidžia šaliai sutaupyti gynybos sektoriaus sąskaita, neplètojant stiprios kariuomenès ${ }^{23}$. Juolab kad

\footnotetext{
${ }^{19}$ Mînzărari D., Proiectul Concepției securității naționale - test decisiv pentru elita politică moldovenească (note 12), p. 43.

${ }^{20}$ Marandici I., „Moldova's Neutrality: What is at Stake?“ in Quo vadis, Moldova?, Lviv: Multi-M, 2007, p. 47.

${ }^{21}$ Tăbârtă I., Berbeca V., Proiectul CSI: Anatomia unui eşec, Politice publice Nr. 7 2009, IDIS Viitorul, 9

${ }^{22}$ Molodilo D. (note 6), p. 90.

${ }^{23}$ Cebotari S., Saca V., „,Republica Moldova între statutul de neutralitatea şi aderarea la NATO“ in Studii internationale: Viziuni din Moldova. Publicație periodică ştințifico-metodică, Nr. 3(4), 2007, p. 68.
} 
dabartinëje tarptautinëje sistemoje valstybei, siekiančiai užsitikrinti nacionalinị saugumą, stiprios kariuomenès nepakanka ${ }^{24}$. Taigi lèšas, sutaupytas „griežtojo" saugumo plètros sąskaita, galima skirti kitoms valstybès reikmėms, taip stiprinant „švelnujį “ šalies saugumą (taip išvengiant vadinamojo „saugumo paradokso").

Nors neutraliteto strategiją besirenkančios valstybės paprastai siekia didesnio lankstumo ir manevro laisvès kitose valstybės gyvenimo srityse, saugumo politikoje neutralitetas yra gana nelanksti strategija, apribojanti valstybès veiksmų erdvę iki valstybès sienų. Kitaip tariant, neutralitetas iki minimumo sumažina mažosios valstybès galimybes savo saugumo šaltinių (ar jų kombinaciju) ieškoti už valstybės ribų. Moldovos atveju skubotai pasirinktas neutralitetas kelia nemažai problemų.

Visų pirma, šalies neutralumas privalo būti ne tik deklaruojamas pačios valstybès, bet ir pripažįstamas tarptautinės bendruomenès, t.y. kitos valstybės ar kiti tarptautinių santykių subjektai privalo suvokti (angl. percept) valstybę kaip neutralią. Svarbu ir tai, kad šiandieninëje tarptautinëje sistemoje neutralitetas yra gana retai sutinkama saugumo strategija - neutraliomis pripažistamos arba istoriškai neutralumą sugebejjusios išsaugoti valstybės (pvz. Šveicarija), arba valstybės, kurioms balansuoti tarp didžiuju galiu padeda ekonominiai ištekliai (pvz., Azerbaidžanas). Moldovos atveju tarptautinių santykių subjektai jos nesuvokia kaip neutralios ${ }^{25}$, o Rusija netgi atvirai pažeidžia Moldovos neutralitetą, dislokuodama savo karines pajègas Moldovos teritorijoje. Dèl šios priežasties Moldovos vienašališkai deklaruotas neutralumas veikia geriausiu atveju kaip gairès šalies saugumo politikai, o ne kaip reali saugumo strategija, galinti padèti užtikrinti šios mažos valstybės saugumą.

Antra, mažos valstybės, esančios aukštos geopolitinės įtampos zonoje, saugumui užtikrinti būtinas ,išorinis“ saugumo šaltinis - valstybè ar ju grupè, teikianti mažajai valstybei saugumo garantijas ${ }^{26}$. Šalies neutralitetas taip pat turi būti garantuotas "iš išorès", formaliais ar neformaliais tarptautiniais mechanizmais. Tačiau Moldovos neutralitetas neturi jokio garanto „iš išorès" - nei formalaus, nei neformalaus ${ }^{27}$. Dar daugiau, neutraliteto statusas riboja Moldovos išorinį bendradarbiavimą saugumo srityje.

Trečia, Moldovos neutralitetas neatlieka pagrindinès savo kaip saugumo strategijos funkcijos - neužtikrina Moldovos saugumo. Kaip tik jis prisideda prie permanentinio nesaugumo situacijos „konservavimo“. Separatistiniame

\footnotetext{
${ }^{24}$ Gorincioi R., „Developing National Security Concept and Strategy: Assessing Existing Needs and Risks“ in European and NATO Neighbouring Policies - New Dimensions for Regional Cooperation, Training seminar, Chisinau, Republic of Moldova, November 28-29, 2007, p. 52.

${ }^{25}$ Mocanu Gh., 100 cele mai presante probleme ale Republicii Moldova in 2008, IDIS Viitorul, Chişinău, 2009 , p. 243.

${ }^{26}$ Spiegel S., Dominance and Diversity. The International Hierarchy. Boston, 1972, p. 133, 136. Paimta iš: Amstrup N., "The Perennial Problems of Small States: a Study of Research Efforts", Cooperation and Conflict. Nordic Journal of International Studies. Vol IX, No. 3, 1976, p. 170.

${ }^{27}$ Munteanu I. et al, Moldova pe calea democrației şi stabilității din spațiul post-sovietic în lumea valorilor democratice, IDIS Viitorul, 2005, p. 247.
} 
Padniestrès regione dislokavus Rusijos karines pajėgas, Moldova tapo bejègè ne tik „,spausti“ Padniestrę dèl konflikto sureguliavimo, bet ir ieškoti pagalbos už savo sienų. Kaip jau minėta, didžiausia grèsmė Moldovai kyla lokaliu lygmeniu, taigi neutralitetas, iš esmès skirtas valstybei ,,išvengti aukštos geopolitinès įtampos", šiuo atveju nèra optimali saugumo strategija.

Ketvirta, Moldovos deklaruotas neutralitetas stabdo šalies karinių pajègu stiprinimo ir modernizavimo procesą. Nuolatinis šalies neutralumo principas, nors ir įtvirtintas Konstitucijoje, strateginiuose dokumentuose nèra paaiškintas. Toks neapibrèžtas šalies saugumo strategijos pagrindas rodo, kad politikai nelabai įsivaizdavo, kaip neutraliteto strategija turètų veikti Moldovos atveju. Dèl šios priežasties Moldovoje ,ǐ̌šaldoma“ dar iš sovietmečio „paveldèta“ situacija karinèse pajėgose, stabdomos reikalingos reformos ${ }^{28}$, o tai silpnina šali ne tik iš išorès (kaip patikimą partnerį), bet ir iš vidaus.

Galiausiai valstybès saugumo strategijos funkcija - ne tik garantuoti gyvybiškai svarbų išlikimą, bet ir prisidèti prie nacionalinių interesu igyvendinimo $^{29}$. Silpnas Moldovos nacionalinių interesu artikuliavimas - viena pagrindinių priežasčiu, trukdančių šaliai pasirinkti efektyvią saugumo strategiją ir verčiančiu ją laikytis deklaratyvaus neutraliteto. Kita vertus, neutraliteto strategija „blokuoja“ šalies nacionalinių interesų peržiūrëjimą. Taigi susidaro „užburtas ratas“ - Moldova neperžiūri savo saugumo strategijos, nes yra priversta laikytis deklaruotos neutraliteto strategijos.

Kaip matome, nuoseklus „deklaratyvaus“ Moldovos neutraliteto laikymasis ne tik kad neprisideda prie šalies saugumo užtikrinimo, bet ir gali didinti Moldovos nesaugumą, o pakeisti Konstitucijoje įtvirtintą nuolatinio neutraliteto principą galima tik referendumo keliu (142 str. 1 dalis) ${ }^{30}$. Tuo tarpu viešosios nuomonès apklausos rodo, kad didžioji dalis Moldovos visuomenès $(2009 \mathrm{~m}$. lapkritic - 58,5 proc.) mano, kad neutralitetas yra geriausia strategija, leidžianti užtikrinti šalies saugumą̧

Toks neutraliteto populiarumas šalies visuomenëje gali būti paaiškinamas keletu aspektų. Visų pirma, Moldovos visuomenė, dešimtojo dešimtmečio pradžioje išgyvenusi kad ir nedidelio masto, bet visgi ginkluotą konfliktą su separatistiniu Padniestrès regionu, turi vilties, kad neutralitetas užkirs kelią ginkluotiems konfliktams pasikartoti ateityje. Kitaip tariant, Moldovos visuomenè neutralitetą vertina ne dèl to, kad esant tokiai saugumo strategijai šalies saugumo situacija gerèja, o dèl to, kad neutralitetas leidžia šiai situacijai bent jau neblogèti. Antra, ankstyvasis Moldovos transformacijos etapas, sutapęs su prorumuniškos politikos laikotarpiu, daugeliui gyventojų sukèlè nusivylimą

\footnotetext{
${ }^{28}$ Busuncean T., „Controlul democratic asupra reformei sectorului de securitate în Republica Moldova“ in Studii Internationale: Viziuni din Moldova. Publicație periodică ştinţifico-metodică, Nr. 3(4), 2007, p. 55-56.

${ }^{29}$ Gorincioi R., „Developing National Security Concept and Strategy: Assessing Existing Needs and Risks“ (note 24), p. 57, 59.

${ }^{30}$ Constituția Republicii Moldova (note 10).

${ }^{31}$ Barometrul Opiniei Publice, Republica Moldova, Noiembre 2009, Institutul de Politice Publice, p. 110. Paimta iš http://www.ipp.md/files/Barometru/2009/final_bop_noiembrie_2009_recap.pdf [2009-12-21]
} 
(ypač - socialinëje ir ekonominëje srityje). Taigi neutralitetas dalies Moldovos visuomenės suvokiamas kaip „saugiklis“ nuo prorumuniškos politikos nesėkmių ateityje.

„Moldaviškasis" neutralitetas vienu metu kenčia iškart nuo dvieju ydu - jis yra netinkamai pasirinktas esamai saugumo situacijai ir netinkamai vykdomas.

Netinkamo pasirinkimo atveju susidaro situacija, kai valstybė daugiau paaukoja savo saugumo politikos srityje nei gauna už tai mainais. Tokią padètí galima ịvardyti kaip savotišką „nuostolį“, neigiamai veikiantį ne tik saugumo, bet ir kitas sritis (pvz. užsienio politiką) ir potencialiai mažinantį šalies struktūrinę galią. Netinkamas neutraliteto strategijos vykdymas apima keletą veiksnių: išorinius, nuo Moldovos tiesiogiai nepriklausančius (,„išaldytas“ konfliktas su Padniestre, Rusijos kariuomenès buvimas Moldovos teritorijoje), ir vidinius (Moldovos valdžia neutralitetą suvokia ne kaip balansavimą, o kaip neveikimą). Moldovos valdžiai pakeitus požiūrị i̇ neutralitetą, t.y. suvokus, kad ir šalies neutralumą galima užtikrinti aktyviomis pastangomis, palaipsniui nebeliktu ir išorinių kliūčių neutralitetui.

Pagrindinių sąlygų neutraliteto strategijai veikti sudarymas gerokai sumažintų grèsmę šalies saugumui (negatyvus saugumo strategijos tikslas). Tačiau tinkamas neutraliteto vykdymas neišsprendžia netinkamo pasirinkimo problemos - net ir sklandžiai veikiantis, Moldovos neutralitetas būtų savitikslis, o tai ribotų šalies struktūrinès galios didējimą (pozityvus saugumo strategijos tikslas).

\section{Moldovos neutraliteto veiksniai}

Moldovos taikoma neutraliteto strategija šaliai kelia daugiau saugumo problemų nei pasiūlo jų sprendimo būdụ. Visgi galima teigti, kad tiek deklaratyvaus neutraliteto įtvirtinimas dešimtojo dešimtmečio pradžioje, tiek jo išlaikymas yra Moldovos išorès ir vidaus politikos klausimų specifikos pasekmė, o ne ju priežastis. Kitaip tariant, Moldovos pasirinkimas (kad ir neoptimalus) taikyti saugumo strategiją buvo nulemtas grupès įvairaus intensyvumo veiksnių.

Mažosios valstybės nesaugumo ir saugumo užtikrinimo problemos glaudžiai susijusios su išore - dèl aukšto mažosios valstybės pažeidžiamumo lygio ji yra priklausoma nuo tarptautinės konjunktūros. Tačiau, nors didžiuju galių konfigūracija ir apriboja mažosios valstybės saugumo pasirinktis, galutiniai pasirinkimai priklauso nuo pastarosios politinès valios. Sioje dalyje Moldovos neutraliteto „šaltiniai“ analizuojami remiantis trimis tarptautiniu santykiu teorinėmis prieigomis - realizmu, pliuralizmu ir konstruktyvizmu. 


\subsection{Tapatybès konfliktas ir politinio Moldovos pasirinkimo problema}

Žvelgiant iš konstruktyvizmo perspektyvos, pamatinis veiksnys, lemiantis neutraliteto saugumo strategijos pasirinkimą ir išlaikymą - Moldovos balansavimas tarp prorumuniškosios ir promoldaviškosios politinès tapatybės.

Dèl sudètingos ir nevienaprasmiškai interpretuojamos Moldovos istorijos $^{32}$, sovietmečio „palikimo“ ir fragmentiškos nepriklausomos Moldovos tapatybès politikos šiuo metu šalyje egzistuoja gili takoskyra tarp dvieju konfrontuojančiu valstybės tapatybės sampratu -rumuniškosios ir moldaviškosios.

Kova dèl nepriklausomybės Moldovoje prasidëjo nuo tautinio - rumuniškojo - judejjimo. $1989 \mathrm{~m}$. rugpjūčio 27 d. prasidëjo tautinis-intelektualinis judejjimas, igavęs Didžiojo susirinkimo (rum. Adunarii Mare) pavadinimą. Didžiojo susirinkimo, peraugusio ị keletą dienų trukusį masinį protestą, metu buvo suformuoti šie reikalavimai: rumunu kalbos kaip valstybinès kalbos iteisinimas, suverenitetas Moldovai ir naujos Konstitucijos priemimas. 1989 m. rugpjūčio 31 d. po labai itempto Moldovos TSR Aukščiausiosios tarybos (AT) posèdžio tuometinis AT pirmininkas Mircea Sneguras (po to tapęs pirmuoju nepriklausomos Moldovos prezidentu) paskelbė rumunų kalbą oficialia Moldovos SSR kalba. Beveik po dvejų metu - $1991 \mathrm{~m}$. rugpjūčio $27 \mathrm{~d}$. - priimtoje Nepriklausomybės deklaracijoje taip pat fiksuojama, kad 1989 m. rugpjūčio 31 d. Didžiojo susirinkimo metu priimtas sprendimas valstybine paskelbti rumunu kalbą. Moldovos vèliava, siekiant pabrèžti dviejų tautų bendrumą, pasirinkta Rumunijos trispalvė su Moldovos herbu vèliavos centre. Valstybės himnu tapo Rumunijos himnas „Prabuskite, rumunai“ (rum. „Deşteaptă-te, române!“)33.

Panašūs procesai tuo metu vyko ir Rumunijoje. Prieš metus nuvertę Nicolae Ceauşescu režimą, rumunai puoselëjo „istorinès teisybės“ atkūrimo viltis ir rèmé nuo SSRS atsiskyrusią Moldovą. Rumunija buvo pirmoji valstybè, pripažinusi Moldovos nepriklausomybę ir užmezgusi su ja diplomatinius santykius, ji pirmoji atidare Moldovoje savo diplomatinę atstovybę ${ }^{34}$. Taigi Moldova nuo pirmujų nepriklausomybės dienų turëjo tvirtą partnerį tarptautineje arenoje.

Moldovos nepriklausomybę tarptautinè bendruomenè, taip pat ir pati Rumunija, laikè tarpiniu žingsniu į abiejų valstybių susijungimą. Tačiau dèl

\footnotetext{
${ }^{32}$ Moldavijos kunigaikštystė susiformavo apie XIV a. vid. Panašiu metu ėmėsi formuotis organizuoti dariniai ir Valakijoje bei Transilvanijoje. XVI a. šios trys rumunų gyvenamos žemés sudare pirmają personaline uniją. $1859 \mathrm{~m}$. vél per bendrą valdovą susijungè dvi rumuniškos žemès - Valakija ir Vakarų Moldova, sudarydamos modernios Rumunijos branduoli. Nauja valstybè $1881 \mathrm{~m}$. oficialiai pavadinama Rumunija. Besarabija - teritorija tarp Pruto ir Dniestro upių, faktiškai sutampanti su dabartinès Moldovos teritorija (išskyrus Padniestrę), nuo $1812 \mathrm{~m}$. buvo okupuota carinès Rusijos. Būtent tuomet atsiranda skirtis tarp pavadinimu „Moldova“, kuris istoriškai apėmè Besarabiją ir Vakarų Moldovą (teritorija nuo Pruto upès iki Karpatŭ, šiuo metu - Rytų Rumunija) ir „Besarabija“ (etninès rumunų žemės tarp Pruto ir Dniestro). 1918 m. pradžioje Besarabija paskelbia nepriklausomybę nuo Rusijos ir prisijungia prie Rumunijos. Bendras Besarabijos ir Rumunijos valstybingumas truko iki 1940 metu.

${ }^{33}$ Caşu I., „Politici identificare în Moldova sovietică şi post-sovietică“, RO-MD/Moldova în două scenarii, Centrul pentru artă contemporară, Chişinău, 2008, p. 67.

${ }^{34}$ Josanu Y. et.al. (note 4), p. 84.
} 
vèliau išryškejjusių nesutarimų Moldova darèsi vis labiau linkusi išlaikyti savo suverenitetą. Neilgai trukus brolystès su Rumunija euforiją ėmė keisti įtampa, peraugusi i priešiškumą, o rumuniškają tapatybę išstūmẻ moldaviškoji.

Vadinamosios moldaviškosios tapatybès egzistavimas - pusę amžiaus trukusios sovietinės propagandos rezultatas. SSRS gyvavimo laikais visais įmanomais būdais buvo siekiama ,ịvaryti pleištą“ tarp Rumunijos ir Moldovos, visu pirma - paneigiant Moldovos gyventojų kaip rumunų tapatybę. Sovietų valdžia dejjo didžiules pastangas, kad neva moksliniais argumentais įrodytų moldavu tautos, kaip atskiro etnoso, egzistavimą. Iš tiesu, istoriniuose šaltiniuose galima aptikti įvardijimą ,moldavas", tačiau , pasak istoriku, tai yra nuoroda ne į etninę priklausomybę, o į teritoriją - taip buvo apibūdinami rumunai, gyvenantys Moldovos Kunigaikštystejje $\mathrm{e}^{35}$. Tuo pat metu sovietiniai moldavistikos tyrejjai bande įrodyti, neva moldavų tauta yra lingvistiškai ir kultūriškai besiskirianti nuo rumunu ir turinti kitą istorinès raidos kelią. Šiam skirtingumui pabrèžti buvo „,sukurta“ moldavų kalba - moldavų kalba pavadinta kirilica perrašyta rumunų kalba. Dar daugiau, sovietinès Moldovos pilietis galejo save sutapatinti su kuo tik norèjo - moldavu, rusu, ukrainiečiu, gagaūzu, žydu, bulgaru, tik jokiu būdu ne su rumunu. Už viešą pareiškimą, kad esi rumunas, grèsė net baudžiamoji atsakomybė, kaip už nacionalizmo kurstymą ar net veiksmus prieš Moldovos SSR teritorini integralumą. Beje, kaltinimai nacionalizmo kurstymu galëjo būti pareikšti ir dèl „pernelyg taisyklingos" kalbos vartojimo. ${ }^{36}$

Sovietmečiu įskiepyta moldaviškoji tapatybė vèl pasireiškẻ 1994-aisiais Moldovos Konstitucijoje valstybine kalba įvardijama (neegzistuojanti) moldavu kalba $^{37}$, siekiant pabrèžti savarankiškumą nuo Rumunijos. Dar daugiau, tais pačiais metais priimtas sprendimas pakeisti šalies himną - vietoje „Prabuskite, rumunai!” pasirinktos Alexandro Mateevici eilès „Mūsų kalba“ (rum. ,,Limba noastră “). Rumunijos kaip priešiškos jègos, pavojingos Moldovos suverenitetui, vaizdavimas tęsèsi iki pat 2005-uju metų. Rumuniškosios tapatybės išstūmimui pasitarnavo ir ekonominiai sunkumai. $1994 \mathrm{~m}$. Moldovoje buvo stebimas precedento neturintis ekonomikos smukimas, kai šalies BVP, palyginti su $1989 \mathrm{~m}$. rodikliais, sumažèjo net 50 procentų. Po keleto metų - 1998 m. - Moldova pajuto Rusijos krizès pasekmes. Viena vertus, esant ekonominiams sunkumams, tapatybès klausimai žmonèms tampa antraeiliai. Kita vertus, užklupus sunkumams, buvo populistiškai išnaudojama aliuzija ì "gerus" sovietinius laikus, o tai didino į moldaviškają tapatybę apeliuojančių politiniu jẻgu populiarumą. Be to, nemažą įtaką atsitraukimui nuo rumuniškosios tapatybès turèjo ir Rusijos veiksnys.

2005 m., Moldovai išsikèlus eurointegracijos tikslą, tuometinė komunistų vyriausybė buvo priversta švelninti toną Rumunijos atžvilgiu. Tačiau santykiai

\footnotetext{
${ }^{35}$ Timpul, Pâslariuc V., „,650 ani ai „statalității moldoveneşti“, proiect al elitelor „,bugetovore“““, Interviul de luni, $2009 \mathrm{~m}$. vasario $23 \mathrm{~d}$.

${ }^{36}$ Casu I. (note 33), p. 64.

${ }^{37}$ Sprendimas grižżi prie lotynų alfabeto priimtas 1989 m. rugpjūčio 31 d., tad jei moldavų kalba buvo vadinta rumunų kalba, perrašyta kirilica, tai Konstitucijos priëmimo metu kalbos vadinti „moldavų“ nebuvo jokio pagrindo.
} 
su Rumunija ir toliau išliko įtempti, o komunistai tęsė neigiamo Rumunijos įvaizdžio eskalavimą. Moldovos santykiai su Rumunija pasiekẻ aukščiausią įtampos tašką po 2009 m. pavasarį kilusių masinių protestų, kurių režisavimu komunistu vyriausybè apkaltino Rumuniją. Tuomet kaimyninès valstybès piliečiams Moldova įvedè vizų režimą.

Tačiau visuomenëje vyko priešingas procesas: 2003 m. Moldovoje panaikinus dvigubos pilietybės draudimą, norą tapti Rumunijos piliečiais pareiškè per milijoną Moldovos piliečiu, iki šiol pilietybẻ suteikta daugiau nei 120 tūkst. moldavu.

Naujas Moldovos ir Rumunijos santykiu etapas prasidejjo po 2009 m. liepos 29 d. ívykusių pirmalaikiu parlamento rinkimu, kuriuos nedidele persvara $^{38}$ laimèjo buvusios opozicinès partijos, susivienijusios į aljansą „Už Europos integraciją". Naujoji prorumuniška Moldovos vyriausybė nedelsiant panaikino komunistų vyriausybės įvestas sankcijas Rumunijai ir pasuko glaudesnių santykių su pastaraja link. Moldovos ministras pirmininkas Vladas Filatas pirmo oficialaus vizito Briuselyje metu viešai pareiškè, kad jo gimtoji kalba yra rumunu ${ }^{39}$ (tai buvo pirmasis toks viešas pareiškimas nuo 1994-uju), o 2009 m. pabaigoje oficialiuose Moldovos valdžios institucijų elektroniniuose tinklalapiuose kalbos pasirinktis iš "moldavu“" (MD) pakeista ì „rumunu“ $(\mathrm{RO})^{40}$. Savo ruožtu Rumunija yra pasirengusi dar labiau padidinti pilietybès suteikimo mastą ir, pradedant nuo 2010 m., kasmet Rumunijos pilietybę suteikti iki 100 tūkst. moldavuc ${ }^{41}$.

Dèl stabilios politinès tapatybès nebuvimo Moldovos saugumo politika yra „pakibusi“ tarp Vakaru (visu pirma - Rumunijos, taip pat - ES ir NATO) bei Rytu (Rusijos ir NVS erdvès). Kaip taikliai pastebi Charlesas Kingas, devintajame dešimtmetyje Besarabijos rumunai prabudo, bet pamiršo išlipti iš $\operatorname{lovos}^{42}$. Tokia situacija atvede šali prie neutraliteto, kuris politiškai yra ne kas kita, kaip nežinojimo, ties kuria tapatybe apsistoti, pasekmė.

Geopolitiškai Moldova neturi aiškios priklausomybès konkrečiam regionui. Taigi nuo vyraujančios tapatybès krypties priklauso regiono, prie kurio siekia prisiskirti Moldova, nusistatymas (Pietryčių Europa, Juodosios jūros regionas, Rytų Europa, NVS erdvè). Regiono pasirinkimas visų pirma palengvintu rasti potencialų saugumo šaltini, kurio atžvilgiu reiktų kreipti savo saugumo politiką, antra, konkrečiau apibrèžti grèsmes ir jų neutralizavimo būdus.

\footnotetext{
${ }^{38}$ Keturių partijų porinkiminis aljansas „Už Europos integraciją“ gavo 53 vietas 101 vietų parlamente, komunistu partija - 48 mandatus.

${ }^{39}$ Radio Free Europe/Radio Liberty, Moldovan Premier Wants „,Clear EU Perspective“, Financial Aid, $2009 \mathrm{~m}$. rugsèjo $30 \mathrm{~d}$.

${ }^{40}$ Radio Free Europe/Radio Liberty, Moldovan Government Switches to „, Romanian “ Language on Websites, 2009 m. lapkričio $28 \mathrm{~d}$.

${ }^{41}$ Rodkiewicz W., From "virtual” to European Democracy - the Origins and Consequences of the Political Breakthrough in Moldova, Centre for Eastern Studies, Warsaw, December 2009, p. 79

${ }^{42}$ King Ch. (note 7), p. 224.
} 


\subsection{Nuolatinis neutralitetas kaip Moldovos „neutralizavimas“}

Sovietmečiu „,suskaldyta“ Moldovos tapatybė davè pradžią ir konfliktui su Padniestre įsiplieksti, kuris netrukus buvo ,į̌aldytas“ ir virto didžiausia grèsme Moldovos saugumui. Žvelgiant iš realistinès perspektyvos, Moldova nuo pat nepriklausomybės pradžios susiduria su nuolatine "griežtojo" saugumo grèsme. Dar daugiau, ši grèsmė yra aukščiausio intensyvumo - grèsmė valstybès teritoriniam integralumui. Po 2008 m. rugpjūčio Gruzijos-Rusijos karo, suformavusio kraštutinio „išsaldytu“ "konfliktų panaudojimo precedentą, "griežtojo" saugumo grèsmès Moldovai dar labiau išaugo.

\subsection{1. „Ǐsaldytas“ konfliktas su Padniestre - nuolatinè grèsmè Moldovos saugumui}

Padniestrè - nedidelè teritorija kairiajame Dniestro krante, turinti šiek tiek daugiau nei 500 tūkst. gyventoju - istoriškai Moldovai nepriklausè, o prie Besarabijos buvo prijungta tik sovietmečiu. Sovietineje Moldovoje Padniestrė tapo pramoniniu valstybès centru: regione buvo pagaminama 90 proc. Moldavijos SSR suvartojamos elektros energijos ir sukuriama 40 proc. Moldavijos SSR BVP ${ }^{43}$.

Padniestrẻ buvo apgyvendinta iš visos SSRS atvykusiais rusakalbiais gyventojais, kurie rumunų (tuomet vadinta moldavų) kalbos taip ir neišmoko. 1989 m. rugpjūčio 31 d. buvo priimtas įstatymas dèl rumunų kaip valstybinès kalbos statuso. Netrukus Padniestrëje prasidejo masiniai protestai, peraugę i separatistini judejjimą. Pasak ekspertu, rusakalbiu Padniestrẻs gyventoju protestai neabejotinai buvo suorganizuoti (surežisuoti), nes taip operatyviai sureaguoti i valstybinès kalbos klausimą rusakalbiai regiono gyventojai vargu ar galëjo ${ }^{44}$. Tačiau kalbos ịstatymas tapo pretekstu separatistiniams procesams Padniestrëje igauti pagreiti. Neva argumentuodami „rumuniškojo nacionalizmo" baime, $1990 \mathrm{~m}$. rugsejjo $2 \mathrm{~d}$. vadinamoji Padniestrès Moldovos respublika (PMR) paskelbė atsiskirianti nuo Moldovos, išsirinko de facto prezidentą (juo jau ketvirta kadencija iš eilès yra Igoris Smirnovas) ir prièmè Konstituciją. Moldovai nesutikus su regiono atsiskyrimu, 1990 m. rudenį Dubesaryje (Dubロsari) ir 1992 m. pavasarị Benderuose įvyko Moldovos pajègu susidūrimai su Padniestrès de facto pajëgomis. $1992 \mathrm{~m}$. vasarą susidūrimo Benderuose malšinti Rusija pasiuntė 14-ąją armiją - rezervistų pajègas. Numalšinusi neramumus, 14-oji armija Padniestreje pasiliko saugoti regione likusios Rusijos ginkluotės. 2000 m. Padniestrëje buvo apie 42 tūkst. tonų Rusijos ginkluotès. ESBO duomenimis,

${ }^{43}$ Trilateral Plan for Solving the Transnistrian Issue. Regional Partnership for a Common Commitment Oriented Approach. Policy paper, developed by Moldova-Ukraine-Romania expert group. Bucharest-Chisinau-Kiyv, January 2006, p. 14.

${ }^{44}$ Iš pokalbio su buvusiu Moldovos Ministru patarèju Rumunijoje, dr. Gheorghe Căldare, 2009 m. spalis, Kišiniovas. 
per 2000-2004 m. laikotarpị iš Padniestrès buvo išvesta (išgabenta ar sunaikinta) 50 proc. visos ginkluotės ${ }^{45}$. Šiuo metu Moldovos teritorijoje yra 1500 rusų karių ir per 20000 tonu amunicijos.

1992 m. liepos 21 d. Rusija, Moldova ir Padniestre pasirašè susitarimą dèl ugnies nutraukimo. Nors Rusija deklaravo atliekanti tarpininko (mediatoriaus) vaidmeni konflikto sureguliavimo procese, Rusijos kaip susitarimo šalies statusas patvirtina faktą, kad Padniestrès konfliktas realiai vyksta ne tarp Moldovos ir atsiskirti siekiančio regiono, o tarp Moldovos ir Rusijos ${ }^{46}$. Be to, šiuo susitarimu buvo „užprogramuota“ dar viena problema. Šiuo dokumentu buvo ikurtos jungtinès taikdariu pajègos, kurias sudarè penki Rusijos, trys Moldovos ir du Padniestrès batalionai, dislokuoti Saugumo zonoje $(10 \mathrm{~km}$ pločio ruožai abipus Dniestro). Tačiau susitarime nenumatytas terminas, kada taikdariu pajègos (kurios didžiaja dalimi yra Rusijos) turès palikti regioną ${ }^{47}$.

1994 m. spalio 21 d. Rusija ir Moldova pasirašė susitarimą dèl Rusijos kariniu pajėgu Moldovos teritorijoje statuso ir buvimo termino, kuriuo Rusija įsipareigojo išvesti savo karines pajejgas iš Moldovos per trejus metus nuo susitarimo įsigaliojimo dienos ${ }^{48}$. Tačiau šio susitarimo Rusija net nepradejjo vykdyti.

Nuo 1997 m. derybos dèl Padniestrès konflikto sureguliavimo vyksta vadinamuoju ",5+2“ formatu (Moldova, Padniestré, Rusija, ESBO ir Ukraina plius du stebėtojai - JAV ir ES, kurie buvo įtraukti $2005 \mathrm{~m}$.). Derybos, deja, vyksta neefektyviai dèl galios asimetrijos: Rusija realiai turi du balsus prieš vieną Moldovos balsa, o visos kitos šalys yra veikiau stebètojai, o ne tarpininkai. Taip pat tiesioginiai Moldovos ir Padniestrės atstovų susitikimai pastaruju „iniciatyva“ yra visiškai „,apmirę" (nevyksta jau aštuonerius metus), ir tai rodo vienos iš konflikto šalių nesuinteresuotumą spręsti konfliktą.

2003 m. Maskva Kišiniovui pasiūlè Padniestrès konfliktą spręsti formuojant federacinę valstybę. Moldovos federalizacijos planas, numatytas Kozako memorandume (jo autorius - tuometinis Rusijos Federacijos prezidento administracijos vadovo pavaduotojas Dmitrijus Kozakas), sulaukẻ didžiulio pasipriešinimo tiek iš Moldovos pilietinės bendruomenès, tiek iš ES ir Vakaru pusės. Kozako memorandumas buvo atmestas dèl keleto priežasčių. Pirma, jis numatė neproporcingai didelį Padniestrès atstovavimą bendrose valdžios struktūrose, o tai suteiktų regionui blokuojančią mažumą. Antra, memorandumas numatè, kad Rusijos karinės pajègos Moldovoje pasiliks iki 2020 metu $^{49}$.

\footnotetext{
${ }^{45}$ Asarov B., „Transnistria: riscuri şi provocări militare, politice şi de altă natură“ in Munteanu I. et al, Moldova pe calea democrației şi stabilității din spațiul post-sovietic în lumea valorilor democratice, IDIS Viitorul, 2005, p. 124.

${ }^{46}$ Busuncean T., ,Separatism in the Black Sea and Caspian Sea Region as a Source of International Terrorism”, Combating Terrorism Working Group, PfP Consortium https://consortium.pims.org/filestore2/download/2339/ ctwg_separatism_in_the_black_sea.pdf

${ }^{47}$ Trilateral Plan for Solving the Transnistrian Issue. Regional Partnership for a Common Commitment Oriented Approach (note 43), p. 7-9.

${ }^{48}$ Solomon C., Gumeniuc A., "Conflictul Transnistrean şi procesul de negocieri în formatul „5+2،““, $M O L$ DOSCOPIE (Probleme de analiză politică), Nr. 3 (XLII), 2008, p. 176.

${ }^{49}$ Solomon C., Gumeniuc A. (note 48), p. 178.
} 
Moldova, siekianti kuo greitesnio Rusijos karinių pajėgų išvedimo iš savo teritorijos, tai suvokẻ kaip netiesioginę valstybès okupaciją.

"Ičaldytas" Padniestrès konfliktas - pagrindinis grèsmių Moldovos nacionaliniam saugumui šaltinis. Visų pirma, jau vien dèl ,į̌šaldyto“ separatistinio konflikto egzistavimo Moldova susiduria su nuolatine grèsme teritoriniam integralumui.

Antra, Padniestreje dislokuotos Rusijos karinès pajėgos Moldovai kelia realią "griežtojo" saugumo grèsmę, ypač šaliai turint nedideles savas ginkluotąsias pajègas (nedidelè profesionali kariuomenè, skirta palaikyti šalies vidaus tvarkai ir dalyvauti taikos palaikymo misijose $)^{50}$. Kaip parodè 2008 m. Gruzijos precedentas, Rusijos karinès pajègos, esančios šalies teritorijoje, gali būti bet kada panaudotos prieš Moldovą.

Trečia, Padniestrèje likęs Sovietų Sajjungos "palikimas" - didžiulès ginkluotès atsargos - Moldovai yra tiek "griežtojo“, tiek „„̌̌velniojo“ saugumo grèsmè. Didžioji dalis Kolbasnoje (Padniestrè) esančiame ginklų sandèlyje (šaltojo karo metais tai buvo didžiausias ginklų sandèlis Europoje) laikomos ginkluotès yra susidèvejjusi. Specialistų skaičiavimais, Kolbasnoje dislokuota apie 10 tūkst. tonų sprogmenu (trotilo), kurių sprogimas savo stiprumu prilygtų atominès bombos, $1945 \mathrm{~m}$. numestos Hirosimoje, sprogimui ${ }^{51}$. Dèl susidèvèjimo ginklus judinti pavojinga, todèl juos reikia naikinti vietoje. Tačiau siekiant išvengti aplinkosauginių grèsmių (gali labai padidèti Dniestro užterštumas), ginklams naikinti turi būti naudojamos specialios technologijos, kurios yra brangios. Viena iš priežasčiu, kodèl Rusija delsia išgabenti sovietų laiku ginkluotę iš Moldovos teritorijos, yra ta, jog Rusija negali sau leisti naudoti šiuolaikinių ginkluotès naikinimo technologijų.

Ketvirta, Padniestrè, valdoma kriminalinio režimo, yra tapusi regioniniu nelegalios prekybos ginklais „centru“. Padniestrëje ne tik sukauptas didelis ginkluotès kiekis (objektyvumo dèlei reikia pažymėti, kad sovietinė ginkluotė kelia didesnę grèsmę aplinkai nei „griežtajam“ regioniniam saugumui), bet ir funkcionuoja visas ginklu gamybos ciklas. Regione veikia metalurgijos fabrikas, mechaninių ginkluotès dalių gamykla, fabrike „Elektromaş“ gaminami keleto tipų šaunamieji ginklai. Gamykla ",Tolikomaş", gaminanti minų aktyvizavimo elementus, neturi analogo visoje NVS. Be to, yra žinoma, kad Padniestrè tiekẻ ginklus nuo Gruzijos atsiskirti siekiančiai Abchazijai ${ }^{52}$. Taigi Padniestrè gali tiekti ginklus ir teroristinėms bei ekstremistinèms grupuotèms.

Prekyba ginklais - ne vienintelè nelegali veikla Padniestrëje, dèl silpnai kontroliuojamų sienų veikiančioje kaip ,juodoji skylë“ organizuoto nusikalstamumo veiksmams (prekyba narkotikais, žmonèmis) vykdyti. Per Padniestrę gabenami dideli kontrabandos kiekiai. 2005 m. Moldovos (Padniestrès) - Ukrainos pasienyje dislokavus ES sienos apsaugos misiją (EU Border Assistance Mis-

\footnotetext{
${ }^{50}$ Mocanu Gh. (note 25), p. 243.

${ }^{51}$ Busuncean T., ,Separatism in the Black Sea and Caspian Sea Region as a Source of International Terrorism" (note 46).

${ }^{52}$ Asarov B. (note 45), p. 129-130.
} 
sion - EUBAM), kontrabandos kiekis gerokai sumažèjo, tačiau vis vien išlieka aukštas. Vien per $2008 \mathrm{~m}$. Moldovos-Ukrainos pasienyje tik oficialiuose sienos kirtimo punktuose sulaikyta per 300 kontrabandinių kroviniu, kurių vertė siekia $1 \mathrm{mln}$. euru $\mathrm{u}^{53} .2006 \mathrm{~m}$. kovo 3 d. Moldova ir Ukraina pradejo iggyvendinti naują muitinès tvarką, pagal kurią Padniestrès eksporto prekès privalo gauti Moldovos muitinès antspaudus. Padniestrè šią tvarką vadino „ekonominiu genocidu“, ir ją palaikè Rusija, regionui skyrusi humanitarinę pagalbą.

Galiausiai separatistinè Padniestre yra tapusi Rusijos ịrankiu riboti Moldovos užsienio politiką ir išlaikyti šalies neutralumą. Tai puikiai įrodo $2003 \mathrm{~m}$. pasiūlytas vadinamasis Kozako memorandumas, kurị igyvendinus Moldova taptu Rusijos „vasalu“. Dar daugiau, Rusija aktyviai remia nacionalistiniųekstremistiniu jaunimo organizacijų veiklą Padniestreje, ugdančių reintegracijos su Moldova ir proeuropietiškos Moldovos politikos priešininkus. Vienos aktyviausių ir gausiausių iš ju - jaunimo organizacija "Proryv“ („Proveržis“) bei Rusijos nacionalbolševiku partijos jaunimo atšaka. Prireikus jos gali veikti kaip neva vietinès jègos, nepatenkintos Moldovos vykdoma politika. Šioms jègoms jau yra priskiriami du teroro aktai šalyje $-2006 \mathrm{~m}$. pavasarị susprogdinta granata troleibuse Tiraspolyje ir analogiškas išpuolis 2009 m. spali Kišiniove viešojo renginio metu ${ }^{54}$.

Nesureguliuotas Padniestrès konfliktas Moldovą tarptautinëje erdvëje daro „,vieno klausimo“ valstybe ${ }^{55}$ ir trukdo šaliai sulaukti visapusiško tarptautinès bendruomenés dèmesio, o tai trukdo Moldovos plètrai.

Neutraliteto saugumo strategija, turejjusi palengvinti kompromiso su Padniestre paieškas, kol kas nedavė jokių rezultatų. Maža to, būtent tas pats Padniestrès konfliktas, dèl kurio Moldova deklaravo neutralumą, yra pagrindinė kliūtis pripažinti Moldovos neutralumą. Tuo pačiu metu Moldova yra vienašališkai deklaruoto neutraliteto ịkaitė, nes mėginimai keisti saugumo strategiją gali išprovokuoti įšaldyto Padniestrès konflikto perëjimą į aktyvią fazę.

\subsubsection{Iššūkiai Moldovos saugumui po Rusijos-Gruzijos karo}

2008-ujų rugpjūtị netikètai įsiplieskęs Rusijos-Gruzijos karas buvo rimtas signalas, išryškinęs Moldovos saugumo „deficitą" ir paskatinęs diskusijas dèl šalies saugumo politikos efektyvumo.

Visu pirma, Moldova suvokè, kad realiai gali tapti kita Rusijos agresijos auka. Sią grèsmę dar labiau sustiprino faktas, kad Rusija Moldovą jau buvo „baudusi“: 2006-aisiais, Moldovos vynuose neva radus pesticidu, buvo uždraustas moldavišku vynų importas į Rusiją ${ }^{56}$, kuris iki galo nėra atnau-

\footnotetext{
${ }^{53}$ Mocanu Gh. (note 25), p. 238.

${ }^{54}$ Iš pokalbio su IDIS Viitorul asocijuotu ekspertu Mgr. Vitalie Grosu, 2009 m. spalis, Kišiniovas.

${ }^{55}$ Mînzărari D., Ioniță V., In NATO we Trust? Explaining why Moldova Would Need to Join NATO, Discussi papers, Debate on Current Affairs series No. 3, October 2008-January 2009, IDIS Viitorul, p. 7.

${ }^{56}$ Munteanu I. et al, 100 cele mai presante probleme ale Republicii Moldova in 2006 (note 20), p. 77.
} 
jintas iki šiol (tuo pačiu metu buvo įvestas embargo gruziniškiems vynams ir mineraliniam vandeniui). Rusijos rinkai iki importo apribojimo teko apie 90 proc. Moldovos vyno pramonès produkcijos, tad abejonių nekelia, kad Rusijos rinkos uždarymas turèjo politines priežastis - tai buvo „atpildas “ už sustiprëjusią Moldovos eurointegracinę ir euroatlantinę politiką. $2005 \mathrm{~m}$. buvo pasirašytas trimetis Moldovos-ES veiksmu planas, $2006 \mathrm{~m}$. - Moldovos-NATO individualios partnerystès veiksmu planas (IPVP), $2005 \mathrm{~m}$. Moldovos-Ukrainos pasienyje dislokuota ES sienos apsaugos misija (EUBAM).

Antra, po Rusijos-Gruzijos karo grèsmè Moldovos teritoriniam integralumui tapo realesnè nei bet kada iki tol. Po to, kai Rusija de jure pripažino separatistinius Abchazijos ir Pietų Osetijos regionus, dar labiau išaugo tikimybė, kad ji bet kuriuo metu analogiškai gali pasielgti ir Padniestrès atžvilgiu. Beje, įdomu tai, kad Rusija neva išaugusią įtaką Moldovai pademonstravo netrukus - jau kitą dieną po Abchazijos ir Pietų Osetijos de jure pripažinimo Moldovai buvo primintas Kozako memorandumas, kuris pastarosios buvo atmestas dar 2005 metais $^{57}$.

Trečia, ginkluotas Rusijos ir Gruzijos konfliktas visą Rytų Europos regioną, ir taip buvusi , „pilkojoje zonoje“, istūmè į dar gilesnį saugumo vakuumą. Dar 2008 m. balandị vykusiame NATO viršūnių susitikime Bukarešte Gruzijai ir Ukrainai buvo atsisakyta suteikti Narystès veiksmų planą, o po Rusijos-Gruzijos karo apie realias Gruzijos ir Ukrainos narystės Aljanse perspektyvas iš viso nebekalbama. Jungtinių Valstiju, 2009 m. pasukusių nauju santykių su Rusija gerinimo keliu, dèmesys Rytų Europai gerokai sumažèjo. Kita vertus, po 2008 m. rugpjūčio galutinai atmestas ir Rusijos, kaip galimo saugumo garanto, vaidmuo. Taigi šiuo metu Rytų Europos šalims, įskaitant ir Moldovą, belieka tik laukti, kaip pasibaigs nauju Rusijos ir Vakarų santykių etapu vadinami procesai.

Šiuo metu vykstantys globalios saugumo aplinkos pokyčiai ir padidejjusi itampa regione po $2008 \mathrm{~m}$. Rusijos-Gruzijos karo neeliminuoja Moldovos neutraliteto saugumo strategijos problemų. Priešingai, Gruzijos atvejis parodè, kad karinès jẻgos panaudojimas prieš valstybę vèl tampa vienu iš užsienio politikos priemonių tarptautineje arenoje ${ }^{58}$, todèl saugumo garantijų klausimas mažajai valstybei yra pirminès svarbos.

Moldova, suvokdama, kad gali tapti Gruzijos precedento tęsiniu, yra linkusi remtis NATO kaimynystès veiksniu - šalies valdžia tikisi, kad Rusija nesiryš pulti šalies, turinčios bendrą sieną su NATO nare Rumunija ${ }^{59}$. Tai vienas iš argumentų dabartinei valdančiajai koalicijai stiprinti ryšius su Rumunija, teikiančia netiesioginį saugumo „skydą“ Moldovai. Vis dèlto, nepaisant augančios Rumunijos veiksnio Moldovos saugumo politikoje svarbos, trumpuoju ir vidutiniu laikotarpiu Rumunijos įtaka kaimyninès Moldovos saugumo strategijai turètu

\footnotetext{
${ }^{57}$ Markedonov S., „The Georgian Crisis“ New Realities and Rules of Game“ in The Black Sea Region: a Security Minefield or a Partnership Road, \#4 Disscussion papers, Intra-regional perspective of the Black Sea Affairs.

${ }^{58}$ Mînzărari D., Ioniță V., In NATO We Trust? Explaining Why Moldova Would Need to Join NATO (note $55)$, p. 18.

${ }^{59}$ Mocanu Gh. (note 25), p. 225-226.
} 
išlikti netiesioginio pobūdžio. Paradoksalu, bet tiesioginè Rumunijos parama Moldovai saugumo srityje šiuo metu gali sukelti priešingą efektą. Pirma, kaip jau buvo minėta, nemaža dalis Moldovos visuomenės iki šiol yra rumunofobiška. Taigi, kuo labiau didètų Rumunijos parama Moldovai, siekiančiai atsitraukti nuo nuolatinio neutraliteto, tuo aktyviau visuomenė remtų neutraliteto išlaikymą. Antra, Rusija ì Moldovos santykių su Rumunija plètrą, ypač saugumo srityje, reaguoja kur kas jautriau nei į šalies bendradarbiavimą su NATO.

\subsection{NATO klausimas Moldovos saugumo darbotvarkèje}

Vienas pagrindinių Moldovos neutraliteto strategijos trūkumų - ribotos partnerių saugumo srityje paieškos galimybès. Tačiau, žvelgiant iš pliuralistinės perspektyvos, Moldova visgi rado būdą apeiti nelanksčią saugumo strategiją, užmegzdama bendradarbiavimą su Vakarų saugumo struktūromis, visų pirma su NATO. Vienas iš argumentu, Moldovai renkantis neutraliteto strategija, buvo nenoras jungtis prie saugumo struktūru, kuriose Rusija dominuoja. Moldova iki šių dienų sẻkmingai apeina visus NVS saugumo dimensijos klausimus (nedalyvauja pratybose ir pan.). Tačiau tuo pat metu neutralitetas leidžia Moldovai plètoti bendradarbiavimą su NATO, nesukeliant aršios Rusijos reakcijos.

Moldovos bendradarbiavimas su NATO prasidèjo 1994 m., Moldovai prisijungus prie Partnerystės taikos labui (angl. Partnership for Peace - PfP) programos. Moldova tapo antraja NVS valstybe (po Ukrainos), prisijungusia prie $\mathrm{PfP}^{60}$. Iddomu tai, kad metais vèliau prie PfP prisijungusi Malta po valdžios pasikeitimo pasitraukė iš bendradarbiavimo su NATO programos, argumentuodama ši žingsni siekiu išlaikyti šalies neutralumą ${ }^{61}$.

1997 m. Moldova prisijungè prie Partnerystès planavimo ir peržiūros proceso (angl. Partnership Planning and Review Process - PARP), tais pačiais metais su Aljansu pradèjo bendradarbiavimą mokslinëje srityje ${ }^{62} .2006 \mathrm{~m}$. Moldovai buvo suteiktas Individualios partnerystès veiksmų su NATO planas (angl. Individual Partnership Action Plan - IPAP), pritaikytas prie šalies nuolatinio neutraliteto statuso ir ES integracijos siekio ${ }^{63} .2006 \mathrm{~m}$. rudenį NATO Moldovoje surengè dvejas karines pratybas - Cooperative Longbow ir Cooperative Lancer 2007 $\mathrm{m}$. šalyje buvo surengtos daugiašalès pratybos Medceur- $07^{64}$.

Pagrindinis Moldovos neutraliteto privalumas bendradarbiavimo su NATO kontekste - santykių su NATO plètra - neišprovokuoja audringos Rusijos reakcijos (priešingai nei Gruzijos ir Ukrainos atveju). Be to, Moldovos visuomenė yra pakankamai pozityviai nusiteikusi NATO atžvilgiu. Analizuo-

\footnotetext{
${ }^{60}$ Druc E., „North-Atlantic Alliance Cooperation Policy: Partnership for Peace“ in European and NATO Neighbouring Policies - New Dimensions for Regional Cooperation, Training seminar, Chisinau, Republic of Moldova, November 28-29, 2007, p. 28-29.

${ }^{61}$ Druc E. (note 60), p. 29.

${ }^{62}$ Druc E. (note 60), p. 30-31.

${ }^{63}$ Druc E. (note 60), p. 33.

${ }^{64}$ Marandici I. (note 20), p. 48.
} 
jant gyventoju požiūrị ị NATO, pastebima įdomi detalè: remiantis viešosios nuomonès apklausomis, atsakydami į klausimą, koks yra optimalus Moldovos saugumo užtikrinimo būdas, už narystę NATO kaip alternatyvą neutralitetui pasisakytu 16,3 proc. apklaustujų. Tačiau į klausimą, kaip balsuotu, jei referendumas dèl Moldovos prisijungimo prie NATO vyktų rytoj, už Moldovos prisijungimą prie Aljanso pasisakè jau net 22 proc. gyventojų ${ }^{65}$. Tokie dviprasmiški rezultatai rodo, pirma, kad Moldovos gyventojai, kaip ir politinis elitas, šalies neutralitetą priima kaip savaime suvokiamą dalyką. Antra, apklausų rezultatai taip pat gali rodyti, kad Moldovoje NATO yra suvokiamas labiau kaip politinè-karinè organizacija, o ne kaip karinis blokas ${ }^{66}$, todèl bendradarbiavimas su Aljansu nèra suvokiamas kaip grèsmė Moldovos nuolatiniam neutralitetui.

Glaudus bendradarbiavimas su NATO Moldovai svarbus dèl keliu priežasčių. Visų pirma, igyvendinant Moldovos-NATO IPVP (dalyvaujant bendrose karinėse pratybose ir kituose renginiuose ir plètojant kitas bendradarbiavimo priemones), Aljansas padeda Moldovai nusistatyti saugumo sektoriaus reformų kryptis, perduoda sukauptą ekspertinę patirtį ir gerają kitų valstybiu patirtį šioje srityje. Atsižvelgiant į neužtikrintą Moldovos valdžios poziciją saugumo sektoriaus reformavimo klausimu, NATO paskatinimas ir pagalba šioje srityje ypač reikšminga. NATO vaidmuo ypač svarbus Moldovai siekiant įtvirtinti demokratinę ginkluotujų pajègų kontrolę, plètoti kariškių ir civilių bendradarbiavimą bei didinti gynybos sektoriaus administravimo skaidrumą.

Antra, bendradarbiavimas su NATO leidžia likti Moldovai euroatlantinëje saugumo darbotvarkëje (Moldovai tapus „tiesiogine“ Aljanso kaimyne, t.y. Rumunijai prisijungus prie NATO, Moldovos svarba Aljansui padidejo). Dar daugiau, NATO - dideliu prestižu tarptautinèje arenoje disponuojanti tarptautinė organizacija - prisideda prie Moldovos kontaktų su Aljanso šalimis plètros. Tiesioginiai kontaktai su minètomis šalimis prisideda prie valstybei žalingo Moldovos kaip „vienos problemos“ šalies įvaizdžio silpninimo.

Trečia, glaudus bendradarbiavimas su NATO yra Moldovos eurointegracinès politikos dalis. Šiuo metu galima kalbėti apie „funkciju pasiskirstymą“ tarp ES ir NATO, kur NATO tenka atsakomybė už euroatlantinės erdvės saugumo užtikrinimą (tai, kad ES plètoja savo karinę dimensija, neprieštarauja NATO vaidmeniui euroatlantinio saugumo srityje). Tai, kad visos naujosios ES narès yra ir NATO narès, yra tiesiogiai susiję su euroatlantinio saugumo užtikrinimo poreikiu.

Taigi, viena vertus, neutralitetas Moldovai leidžia plètoti bendradarbiavimą su Aljansu, „neužkliūnant“ Rusijai. Tačiau, kita vertus, vienašališkai deklaruotas neutralitetas apriboja Moldovos integracijos į NATO galimybes. Narystès Aljanse galimybès eliminavimas iš Moldovos saugumo politikos rimta problema ${ }^{67}$.

\footnotetext{
${ }^{65}$ Barometrul Opiniei Publice, Republica Moldova, Noiembre 2009(note 31), p. 110-111.

${ }^{66}$ Munteanu I. et al, 100 cele mai presante probleme ale Republicii Moldova in 2006 (note 17), p. 211.

${ }^{67}$ Gorincioi R., „Elaborarea noi concepți de securitatea naționala prin prisma cooperăriicu Alianța NordAtlantică“ in Studii internationale: Viziuni din Moldova. Publicație periodică ștințifico-metodică, Vol. IV, Nr. 3, 2007, p. 18.
} 
Visu pirma, jei Moldova siekia realios eurointegracijos (rengiasi vieną dieną tapti visateise ES nare), be narystès NATO tai padaryti bus labai sudètinga dèl keleto priežasčių. Pirma, mažai tikètina, kad ES ryžtųsi priimti „neutralią“ Moldovą ir prisiimti atsakomybę už jos saugumo užtikrinimą, ypač turèdama omenyje Rusijos veiksnį (ši tendencija galioja visos Rytų Europos atžvilgiu). Antra, NATO - ne tik kolektyvinès gynybos garantijos, bet ir demokratijos bei Vakaru standartų gynybos sektoriuje sklaidos priemonè. Taigi ribotus ryšius su NATO turinčios šalies demokratizacija tiesiog bus lètesnè ir ne tokia visapusiška.

Antra, šiuo metu NATO yra vienintelè euroatlantinė saugumo organizacija, galinti teikti realias saugumo garantijas šalims-narėms. Kitos Moldovai prieinamos universalios ir regioninès saugumo organizacijos yra arba stipriai veikiamos Rusijos (pvz., JTO, ESBO), todèl negalinčios efektyviai prisidèti prie Moldovos saugumo problemų sprendimo, arba veikiančios daugiau kaip politinių diskusijų saugumo srityje „klubai“ (pvz., GUAM).

Trečia, šiandien NATO yra vienintelè politinè-karinè jèga, gebanti vykdyti efektyvų atgrasymą nuo konvencinių grėsmių. Taigi narystè NATO padètu Moldovai išspręsti Rusijos spaudimo ir manipuliavimo problemą, bent jau „kietojo" saugumo srityje ${ }^{68}$.

Be to, Moldovos narystès NATO perspektyva turètų ir teigiamą „,šalutinį poveikị" - tai būtų dar vienas ryšys (bendras interesas) su kaimynine Rumunija, o tai prisidètų prie intensyvesnio dvišalio bendradarbiavimo įvairiais lygmenimis. O suintensyvëję šalių kontaktai ir išaugęs tarpusavio pasitikëjimas (abi šalys atsidurtų po vienu ,saugumo skèčiu“) padètu greičiau įveikti "suskaidytos" tapatybės problemą.

Po $2009 \mathrm{~m}$. liepos mėnesi vykusiu pirmalaikiu parlamento rinkimų i valdžią atëjusios prodemokratiškos jègos į glaudesni šalies bendradarbiavimą su NATO žiūri kur kas palankiau nei iki tol aštuonerius metus valdžioje buvę komunistai. Tačiau kyla grèsmė, kad NATO klausimas gali tapti viena iš takoskyru koalicijos viduje. Dvi iš keturių koalicijos partijų - Liberalų partija ir Liberalų demokratų partija - pasisako už neutraliteto strategijos peržiūrèjimą - tai atvertų kelią narystės NATO perspektyvai, tačiau kitos dvi į koaliciją įeinančios politinès jègos - Demokratų partija ir aljansas „Mūsų Moldova“ linkusios pasisakyti už nuolatinio neutraliteto išlaikymą.

Neutralitetas Moldovai, žvelgiant iš pliuralistinės perspektyvos, reiškia spaudimo glaudžiau bendradarbiauti su Rusija „,neutralizavimą", o ne siekį likti už karinių aljansų kaip tokių ribos. Taigi labai tikètina, kad, nusilpus Rusijos veiksniui, Moldova atsivertų narystės NATO perspektyvai.

\footnotetext{
${ }^{68}$ Mînzărari D., Ioniță V., In NATO We Trust? Explaining Why Moldova Would Need to Join NATO (note 55), p. 34.
} 


\section{Išvados}

Moldovos neutraliteto saugumo strategija, pasirinkta daugiau nei prieš penkioliką metu, taip ir nesugebejo padèti šaliai įveikti pagrindinių saugumo problemų. Neutraliteto strategijos neefektyvumą lėmẻ keletas priežasčių.

Visu pirma, neutraliteto strategija Moldovos atveju nepasiteisino, nes ji buvo klaidingai suvokta. Moldovos neutralitetas, nors ir plačiau nepaaiškinamas strateginiuose dokumentuose, remiasi ne geopolitiniu motyvu - siekiu likti už ",aukštos geopolitinès įtampos" ribu, o "griežtojo" saugumo grèsme - nenoru erzinti Rusijos, dislokavusios šalyje savo karines jejgas, taip pat - integruotis i saugumo struktūras, kuriose dominuoja Rusija.

Antra, pagrindinè neutraliteto strategijos funkcija buvo padèti sklandžiai sureguliuoti konfliktą su Padniestre. Tačiau kadangi realiai konfliktas vyksta ne tarp Moldovos ir separatistinio regiono, o tarp Moldovos ir Rusijos, neutraliteto pasirinkimas buvo didelis Maskvos laimejjimas. Moldovai esant neutraliai, o tai reiškia - be saugumo garantų už valstybès sienu, Rusija igyja galimybę ,išaldyti“" Padniestrès konflikto sureguliavimą tiek, kiek tai reikalinga jos pačios interesams. Lemiamą Rusijos veiksnio įtaką Moldovos saugumo strategijos pasirinkimui rodo ir tai, kad nepriklausomybès deklaravimo metu Moldova jau buvo susidūrusi su separatizmo problema, bet $1991 \mathrm{~m}$. rugpjūčio $27 \mathrm{~d}$. priimtoje Nepriklausomybès deklaracijoje nebuvo nè užuominos į neutralitetą. Lūžis Moldovos saugumo strategijos raidoje įvyko po to, kai buvo pasirašytas susitarimas dèl ugnies nutraukimo tarp Moldovos, Rusijos ir Padniestrès, sudaręs sąlygas neterminuotam Rusijos karinių pajègų buvimui šalies teritorijoje. Taigi galima teigti, kad Moldovos neutralitetas - Rusijos interesu refleksija.

Maža to, neutraliteto strategija ne tik neprisideda prie grèsmių Moldovos nacionaliniam saugumui mažinimo, bet ir kelia pavojų sklandžiam šalies strateginiu tikslų igyvendinimui vidutiniu-ilguoju laikotarpiu. Visu pirma tai pasakytina apie Moldovos narystės NATO perspektyvą. Narystės galimybės atmetimas ilguoju laikotarpiu Moldovai gali „kainuoti“ ir ES narystès perspektyvą.

Vilčių, kad nuolatinio neutraliteto statusas bus persvarstomas, teikia 2010 m. planuojamas vykdyti Moldovos Konstitucijos persvarstymas. Šiuo metu valdžioje esantis „Aljansas už Europos integraciją“ Moldovos institucinės krizès laikotarpi linkęs panaudoti strateginiams šalies tikslams ir gairèms koreguoti. Iki 2010 m. birželio, kuomet turi būti paleistas parlamentas ir paskelbti pirmalaikiai parlamento rinkimai, daugiausia dèmesio Moldovoje bus teikiama išèjimui iš institucinès , aklavietės" ir valdžios organų tarpusavio santykių klausimams. Dar daugiau, praktika rodo, kad ekonominiu sunkumu metu saugumo klausimai visuomenei yra mažiau aktualūs. Taigi artimiausiu metu peržiūrimi saugumo politikos klausimai, tikètina, nesusilauktų pasipriešinimo ",bangos".

Vis dèlto, kaip parodè atlikta analizè, Moldovos neutralitetas yra valstybès „pasimetimo“ naujoje geopolitinëje situacijoje pasekmè. Taigi mechaniškas neutraliteto atsisakymas vargu ar atneštų esminių pokyčių. Moldovos valdžia, siekdama sukurti stabilu pagrindą naujai saugumo strategijai, šiuo metu daugiausia dèmesio turètų skirti Rusijos įtakai mažinti, „supriešintos“ tapatybès problemai spręsti ir ryšiams su kitais tarptautinès arenos veikèjais stiprinti. 